\title{
The Effect of Ownership Rights on Urban Households' Access to Credit in Lahore
}

\section{Misha Saleem*}

\begin{abstract}
Land titling and ownership rights have recently been advocated in policy circles as a powerful tool for poverty reduction. The lack of formal titling prevents the use of property as collateral, and hence prevents the capital embedded in these assets from being "unlocked." Some studies show a fairly insignificant relationship between informal loans and property rights, while others indicate a significant positive relationship between formal loans (credit cards, bank loans, etc.) and land ownership. The objective of this article is to look at the impact of owned titled land on formal and informal loans among urban households in Lahore. Here, formal loans are seen in terms of bank loans and credit cards while informal loans are characterized as loans taken from relatives, friends, or local moneylenders. The findings suggest that land ownership has a positive and significant relationship with formal loans but no relationship with either bank loans or informal loans alone.
\end{abstract}

Keywords: Property rights, land ownership, credit access, formal loans, urban households.

JEL Classification: Q15, O16, D14.

\section{Introduction}

Institutions and their evolution play a key role in shaping the environment in which economic agents interact. Given that property relations are "the backbone of the economic structure of society" (Bardhan, 1989), the codification and enforcement of property rights are considered important preconditions for economic growth and development.

Property rights are defined as registered or titled land, i.e., the legal ownership status of which is sanctioned by a property title or deed that is recognized by the state. The title functions like a contract between the holder and the state, with the latter pledging to recognize the former's rights and protect them. Land registration provides an extra layer of

\footnotetext{
Teaching Fellow, Department of Economics, Lahore School of Economics, Pakistan.
} 
security to the titleholder as it guarantees that no other (registered) title exists that contradicts his/her rights. In essence, it makes the contract between the titleholder and the state verifiable by a third party, i.e., a registrar. A formal title that represents alienable rights increases the collateral value of that land.

While development economists have tried to look at the importance of property rights in economic development, credit provision has gained the reputation of a key tool for mobilizing resources and increasing income for households through channels of increased investment. Together, the relationship between owned property and credit accessibility - and its broad effect on the economy-has gained widespread interest among development economists.

Feder, Onchan, Chalamwong, and Hongladarom (1988) identify two linkages between titles and economic performance. On one hand, land tenure facilitates households and enterprises in gaining access to credit by reducing the asymmetries between borrowers and lenders, and increasing the collateral value of land and the amount of credit available. On the other, it enhances tenure security by reducing any informational asymmetry in the ownership status of the land, which can then be used for investment. Both these linkages lead to an increase in credit demand.

De Soto (2000) emphasizes that a lack of property rights impedes the transformation of wealth owned by the poor into capital. Proper titling would allow people to collateralize their land. In turn, this credit could be invested as capital in productive projects, promptly increasing labor productivity and income, and thus economic development. Also, if land were easier to collateralize, banks would charge a lower interest rate (Besley, 1995). Owned land could also be used for sale, lease, or mortgage by households, providing them with liquidity.

The productivity of land depends on the complementary investments carried out in it, be it agricultural investment or urban/commercial. These investments yield benefits over time while the cost is borne upfront. Thus, any investor will first weigh the risks and costs of bearing the investment against its benefits. One major risk is "tenure insecurity" where the investor faces the risk of land ownership disputes, eviction, or expropriation by the government. Institutional arrangements involving registration systems and land titles help reduce land insecurity. Feder and Nishio (1996) argue that, 
with ownership officially documented and verified, the risk of challenges to ownership is reduced, and the likelihood of having to incur high costs in defending one's possession of land is lower, incentives to invest are enhanced and land productivity is increased.

De Soto (2000) summarizes the importance of owned property in one phrase: "Without representations, assets are dead capital."

Formal capital markets in developing countries-including Pakistan-function very poorly. Presently, Pakistan ranks $113^{\text {th }}$ of 129 countries according to the 2011 International Property Rights Index, ${ }^{1}$ with a score of 4.1 out of 10. De Soto (as cited in Woodruff, 2001) explains why capital markets fail in developing countries as follows:

Capital markets fail for the majority because the majority do not own formally titled property. While the majority of residents in developing countries do own property, ownership of property is secured informally, through neighborhood associations or mafias, for example, rather than through formal titles and a property registration system. The lack of formal titling prevents the use of property as collateral, and hence prevents the capital embedded in these assets from being "unlocked." Entrepreneurs in developed market economies are able to turn their houses into capital to start businesses; entrepreneurs in the developing world are not. This inability to convert such assets into capital is "the major stumbling block that keeps the rest of the world from benefiting from capitalism."

Owned titled land not only helps increase credit demand, it also provides security to the lender, thereby increasing credit supply. The loan market in general comprises formal, informal, and semiformal credit markets. Formal credit consists of loans provided by banks (private or government) in cash or through credit cards, while informal credit includes loans provided by private moneylenders, relatives, and other individuals. Semiformal credit consists of loans provided by various national, international, and private donors in the form of microfinance.

\footnotetext{
${ }^{1}$ A new international index published under the Property Rights Alliance in Washington, DC, and the Hernando De Soto Fellowship Program.
} 
The three types vary in lending terms and conditions. The formal credit market, in particular, does not cater to low-income households because of their inability to provide proper collateral. This inability is, however, due to a lack of formal ownership rights rather than lack of underlying assets. For example, in many rural areas, households own substantial property, mainly land, but do not have access to credit because they fail to provide proper documentation to certify their ownership.

Besley (1995) argues that the formal credit market is generally beset by "enforcement and information problems" while informal lenders often have close contact with borrowers, which reduces the risk of default. This is why access to formal credit relies heavily on the provision of collateral while informal loans involve far less collateral than similar commercial banks.

Some studies (Carter \& Olinto, 2003; Pender \& Kerr, 1999; Place \& Migot-Adholla) show an insignificant relationship between formal loans and owned property, while others indicate a significant positive relationship between formal loans and land ownership (Feder et al., 1988; Field \& Torero, 2006; Galiani \& Schargrodsky, 2010; Lopez, 1996). Galiani and Schagrodsky (2010) additionally show an insignificant relationship between informal loans and credit access.

The objective of this study is to examine the relationship between owned land and access to formal and informal credit among urban households in Lahore, Pakistan. Here, formal loans are looked at in terms of current bank loans (i.e., recent bank loans taken by household heads directly from their banks) or credit card loans (i.e., loans taken by household heads using a credit card). Informal loans are characterized as loans taken from relatives, friends, or local moneylenders.

Using a probit estimation technique, we report some interesting findings. The empirical results show that owned land has a positive and significant effect on access to formal loans (as proposed by theory), although bank loans alone seem to have an insignificant relationship with ownership rights. Informal loans (as expected) show no significant relationship with home ownership status.

Section 2 looks at some of the existing literature on this issue. Section 3 presents the study's hypothesis. Section 4 describes the methodology and data used. Section 5 presents the empirical results and discussion, and Section 6 provides some concluding remarks. 


\section{A Review of the Literature}

The existing literature shows mixed results when examining the economic effects of property rights or land ownership and titling. Many studies examine the effect of owned titled land on credit access, housing investment, agricultural productivity, labor supply, and income (Besley, 1995; Carter \& Olinto, 2003; Deininger, 2003; Deininger \& Binswanger, 1999; Feder et al., 1988; Field \& Torero, 2006; Galiani \& Schargrodsky, 2010; Place \& Migot-Adholla, 1998; Roth, Cochrane, \& KisambaMugerwa, 1994). Most focus on rural areas, although the impact of land ownership is applicable to urban settings as well.

Feder et al. (1988) use data on rural areas of Thailand to find a positive relationship between title and credit-land ownership increases land security, and enables landowners to use their land as collateral to gain access to formal credit at lower interest rates, thereby increasing farm productivity. Hayes, Roth, and Zepeda (1997) support this result with evidence from Gambia, while Deininger and Binswanger (1999) also show that formal land titles positively affect access to credit.

Besley (1995) argues that strong property rights are important for access to credit, and indicates their relative importance in bringing about lower interest rates for households who own land as collateral. The study presents ambiguous results where land rights appear to have a positive effect on agricultural investment in the Ghananian region of Angola, but a less significant impact in the region of Wassa. Carter and Olinto (2003) find that the impact of rural titling programs on credit supply and investment demand in Paraguay is strongly size-differentiated, rationing small producers out of the credit market even when they have titled collateral.

Petracco and Pender (2009) examine the impact of land tenure and titling on access to formal and informal credit for rural households in Uganda. They compare four categories of households: households with and without a customary land certificate, freehold tenure households with and without a title, freehold households with a title versus customary households with a certificate, and freehold households without a title versus households without a certificate. The authors show that, for rural households in Uganda, land tenure has a more significant effect on credit access than land title. There is a statistically significant difference in access to any credit and informal credit between freehold and customary households without a title. Land tenure and title do not 
have a significant relationship with formal credit, due mainly to the limited supply of formal credit for all rural households.

Field and Torero (2006) evaluate the impact on credit of obtaining a property title through a land-titling program in Peru. Their results are somewhat ambiguous as they suggest that property titles are associated with approval rates on public sector loans only when lenders request titles, not otherwise. Galiani and Schargrodsky (2010) look at the effects of land titling on housing investment and credit access. They show that there is a positive relationship between land titling and mortgage credit but no relationship with access to other forms of credit (including informal sources).

Dower and Potamites (2010) show that land titles not only function as collateral, but also have ex ante informational value. Using household survey data on Indonesia, the authors show that formal land titles provide ex ante information about the likelihood of compliance with loan contracts when dealing with borrowers who have no established credit history. Formal land titles increase a household's probability of being offered a formal loan, while the loan size is influenced by whether or not the title is offered as collateral.

Johnson, McMillan, and Woodruff (2002) suggest, more from the business sector's point of view, that land titling is an important factor in gaining access to credit. They hold that, within countries, there is variation in both the perceived security of property rights and in access to bank credit. Given these countries' banking systems, small firms are able to borrow only if they can provide adequate collateral. The implications of this can be extended to households to see whether weak property rights limit households in the same way as they limit firms in gaining easy credit. The study also discusses whether property rights are a sufficient factor in gaining access to external finance.

Finally, De Laiglesia (2004) discusses the theory underpinning the mechanism between property rights and credit by highlighting the strong assumptions that underlie the property rights system, such as that land, credit, and other factor markets should function well.

\section{Hypothesis} hypotheses:

Based on what has been suggested by theory, we test three main 
Hypothesis 1: If an asset (i.e., land) is properly owned, then there is increased access to bank loans.

- $\mathrm{H}_{0}$ : Land title has no significant impact on access to bank loans.

- $\mathrm{H}_{1}$ : Land title has a significant impact on access to bank loans.

Hypothesis 2: If land is properly owned, access to either bank loans or credit cards increases.

- $\mathrm{H}_{0}$ : Land title has no significant impact on access to formal loans.

- $\mathrm{H}_{1}$ : Land title has a significant impact on access to formal loans.

Hypothesis 3: If the household head owns land, access to informal loans increases.

- $\mathrm{H}_{0}$ : Land title has no significant impact on access to informal loans.

- $\mathrm{H}_{1}$ : Land title has a significant impact on access to informal loans.

\section{Methodology}

Our empirical analysis relies on a cross-sectional study carried out by conducting a household survey in ten areas of Lahore: 150 in-person questionnaires were completed, covering a range of income groups. The areas were purposely chosen to represent a diverse cross-section, while the households interviewed within each area were selected at random.

The sample was divided among low-income, middle-income, and high-income areas of Lahore. The areas included were Walton, the Cantonment, Defence, Gulberg, Bhatta Chowk, Charar Pind, Model Town, Nasham-e-Iqbal, Samanabad, and Temple Road. The questionnaire (see Appendix) included close-ended questions on the household's ownership and title, resident status, socio-demographic characteristics, and whether the household head had recently obtained a loan from a bank or informal source. The rest of this section briefly describes the dataset used and the variables' frequencies.

\subsection{Variables}

Table 1 presents the frequencies (in percentage terms) of the sample population of households who have, at some point in time, taken a bank loan or informal loan, or used credit cards with respect to whether or not they have property rights over the land on which they live. The 
table also includes frequencies for the covariates that are included in our estimations, cross-tabulated with titled owned land and land not owned. These variables measure primarily household demographics.

The dependent variables used to measure credit access are all binary responses with values of 0 or 1 , where 1 indicates that a household head has used the source of credit in question, and 0 indicates that they have not. The sources of formal credit include bank loans and credit cards. To determine the effect of ownership rights on access to informal loans, the survey also asked whether households had recently taken a loan from an informal source, i.e., friends, relatives, or local moneylender.

The main independent variable-also a binary response-is the ownership status of land. It is worth mentioning here that our regressions cannot distinguish between the effect of titled property and untitled property on access to credit, and can only measure the effect of titled owned land versus land not owned. Although the survey asked households whether they had a registered title for their land and what their resident status was, most households who owned their place of residence also claimed to have titles. However, there may have been households who owned the land but did not have a property/land title certificate. Our dataset was unable to separate the two types of households. There is also a difference in the quality of title among the areas included in the survey as areas. The Defence area has its own system of transferring ownership through the Defence Housing Authority. 
Table 1: Summary Statistics

\begin{tabular}{|c|c|c|}
\hline Dependent and independent variables & Owned (\%) & $\begin{array}{l}\text { Not owned } \\
(\%)\end{array}$ \\
\hline$N=150$ & $N=107(71 \%)$ & $N=43(29 \%)$ \\
\hline $\begin{array}{l}\text { Household heads who have taken bank } \\
\text { loans (current bank loan =1) }\end{array}$ & 68.75 & 31.25 \\
\hline $\begin{array}{l}\text { Household heads who use credit cards } \\
\text { (credit card =1) }\end{array}$ & 86.05 & 13.95 \\
\hline $\begin{array}{l}\text { Household heads who have taken formal } \\
\text { loans (current formal loan }=1 \text { ) }\end{array}$ & 79.37 & 20.63 \\
\hline $\begin{array}{l}\text { Household heads who have taken informal } \\
\text { loans (current informal loan =1) }\end{array}$ & 71.93 & 28.07 \\
\hline $\begin{array}{l}\text { Household heads aged between } 19 \text { and } 29 \\
\text { (age } 19 \text { to 29) }\end{array}$ & 33.33 & 66.67 \\
\hline $\begin{array}{l}\text { Household heads aged } 56 \text { or above (age } 56 \\
\text { and above) }\end{array}$ & 64.29 & 35.71 \\
\hline $\begin{array}{l}\text { Household heads aged between } 30 \text { and } 55 \\
\text { (age } 30 \text { to 55) }\end{array}$ & 76.11 & 23.89 \\
\hline $\begin{array}{l}\text { Households with monthly earnings of } \\
\text { Rs20,000-60,000 (earn 20,000 to 60,000) }\end{array}$ & 67.35 & 32.65 \\
\hline $\begin{array}{l}\text { Households with monthly earnings of } \\
\text { Rs } 60,000 \text { or above (earn above } 60,000 \text { ) }\end{array}$ & 76.60 & 23.40 \\
\hline $\begin{array}{l}\text { Households with monthly earnings of } \\
\text { Rs20,000 or below (earn below 20,000) }\end{array}$ & 70.37 & 29.63 \\
\hline $\begin{array}{l}\text { Households whose percentage of income } \\
\text { saved per month is above } 5 \% \text { (income saved } \\
=1 \text { ) }\end{array}$ & 74.03 & 25.97 \\
\hline $\begin{array}{l}\text { Household heads educated up to university } \\
\text { level (university }=1 \text { ) }\end{array}$ & 81.40 & 18.60 \\
\hline $\begin{array}{l}\text { Household heads educated up to higher } \\
\text { secondary level (intermediate }=1 \text { ) }\end{array}$ & 41.67 & 58.33 \\
\hline $\begin{array}{l}\text { Household heads educated up to secondary } \\
\text { level or below (primary secondary }=1 \text { ) }\end{array}$ & 81.40 & 18.60 \\
\hline $\begin{array}{l}\text { Households already in debt to a formal } \\
\text { lender (bank in debt }=1 \text { ) }\end{array}$ & 76.00 & 24.00 \\
\hline $\begin{array}{l}\text { Households who have ever used committees } \\
\text { to obtain funds (committee }=1 \text { ) }\end{array}$ & 75.31 & 24.69 \\
\hline
\end{tabular}

Source: Author's calculations. 
The list of other independent variables included was taken from Field and Torero (2006). Although their study looks at the issue differently (they collected their data from banks rather than households, and looked at credit supply to households rather than credit demand), the variables they use apply to our regressions as well. These include household earnings per month measured in rupees, the highest level of education completed by the household head, the age group to which the household head belongs, income earned from other sources (such as rental income, foreign remittances, or home business), ${ }^{2}$ the percentage of income saved by the household, the total number of household members, the number of working members, the gender of the household head, ${ }^{3}$ and the average distance from the nearest bank.

Apart from regular savings, we also use another independent variable-also an informal source of savings and finance-known as a "committee," under which a group of people get together and contribute an equal amount of money to a common pool on a monthly basis. Every month, one member of the group takes the whole sum of money, which is a fixed amount equal to the total contributions to the pool. Some committees use a lottery/draw system to select the person who will get this money each month, while others mutually agree to the order of receipt at the beginning of the committee. The committee ends when all members of the group have received the fixed amount in their turn.

\subsubsection{Dependent Variables}

Table 1 shows that the majority of households (71 percent) in our sample have ownership rights. Among those who own land, only 21 percent have recently taken a bank loan, 35 percent use credit cards, and 47 percent have recently taken a loan from an informal source. This implies that most households use informal rather than formal markets as a source of funds.

The demand for bank loans seems to be unrelated to land ownership, which is puzzling as far as theory is concerned. This result is further strengthened by our regression analysis in Section 5. The data on bank loans may be biased since many households were hesitant to give information on whether they had ever taken loans from banks, and if so, what amount they had taken.

\footnotetext{
2 The variable measuring income earned from other sources is not used in the final estimation because the number of observations was insufficient.

${ }^{3}$ In our survey, all households reported a male household head.
} 
In our sample, out of 43 (29 percent) households who reported using credit cards, 37 (86 percent) owned land while 6 (14 percent) did not. Out of 107 (71 percent) households who did not use credit cards, 70 (65 percent) owned land while 37 (35 percent) lived on land they did not own. Here, we can see some relationship between the use of credit cards and ownership rights. When bank loans and credit cards are combined, we find a much stronger relationship between households who own titled land and those who do not. Among the 42 percent of households who had obtained credit from formal sources, 79 percent owned land.

In total, 57 (38 percent) households had taken informal loans while 93 (62 percent) had not. Of the former, 41 (72 percent) owned land and only 16 (28 percent) did not. If we look at frequencies alone, informal loans appear to have a somewhat stronger relationship with owned land, but our empirical analysis does not show a significant relationship between the two.

\subsubsection{Independent Variables}

Of the control variables used in our regression analysis, age, literacy, and income are categorical variables while committee is a dummy variable. The dependency ratio and average distance between the household and nearest bank are continuous.

The household head's age is divided into three broad categories: (i) young (19-29 years old), (ii) middle-aged (30-55 years old), and old (56 years old or more). Similarly, for the education variable, the most educated household heads are those with a university degree (either under- or postgraduate) while other categories include education levels up to primary/secondary and higher secondary/intermediate. In terms of monthly earnings, households earning more than Rs60,000 per month are classified as high-income, those earning between Rs20,000 and Rs60,000 as middle-income, and those earning less than Rs20,000 as low-income.

As Table 1 shows, 77 percent of the households interviewed had heads aged between 30 and 55, 19 percent had heads older than 56, and only a small fraction, approximately 4 percent, of the sample population had heads aged between 19 and 29. Middle-aged and old household heads are expected to have more access to formal loans than younger heads because the former are likely to have more experience, established businesses, or more property to disclose in case of default (or even have collateral/guarantees to offer). 
The more educated a household head, the higher his or her chances of gaining access to formal loans. From the bank's point of view, this involves a lower default risk. In our sample, 63 percent of the population interviewed held either Bachelor's or Master's degrees, while 29 percent had attained less than secondary level education. Only 8 percent of the population had been educated up to higher secondary level.

The frequencies show that, out of 150 households, 36 percent belong to the Rs20,000-or-below income bracket, 33 percent to the Rs20,000-60,000-income bracket, and 31 percent to the high-income bracket of Rs60,000 or above. Households in higher income brackets are expected to have more access to formal loans. Formal financial markets do not generally cater to low-income households, mainly because of their lending terms and conditions and the inability of low-income households to provide collateral. Our data shows that almost none of the low-income households had applied for a loan. Banks are likely to give more debt to households able to show greater amounts of income in their bank accounts as this helps bank lower their default risk. We expect low-income households to have more access to informal rather than formal loans.

Households who tend to save more are likely to have a lower demand for credit, both as formal and informal loans. The variable included in the regressions is saved income, which takes a value of 1 for households whose monthly savings are equal to or more than 5 percent of income earned, and a value of 0 for those whose monthly savings are less than 5 percent of income earned.

The "average distance" variable measures the average distance between a household and formal lender, i.e., a bank. The maximum value of this variable is approximately $10 \mathrm{~km}$ while the lowest is $1 \mathrm{~km}$, and its mean is $1.75 \mathrm{~km}$. The variable is expected to have a negative relationship with access to formal loans because, as the average distance between a household and the nearest bank increases, the cost of taking out a loan also rises in terms of expenses incurred by travel and the opportunity cost of time spent.

Bank indebtedness shows whether a household has obtained a bank loan in the past. This is different from our dependent variable, which measures whether a household is currently in debt to a bank. Our data shows that 33 percent of all households interviewed had taken a bank loan in the past, of which 76 percent owned titled land. The household's indebtedness is considered because whether or not it is currently in debt to a bank will affect its ability and willingness to re-avail 
formal credit. This variable is expected to carry a positive sign relative to current informal loans. Households that have taken bank loans in the past may still be paying large interest payments; they are expected to now avail more informal loans.

The committee system is a popular source of funds in Pakistan; it acts like a savings scheme as well as a source of informal loans for households. The committee variable is expected to have a negative relationship with formal loans, as the two sources of funds are substitutes for one another. However, it is expected to have a positive relationship with informal loans since most households who take informal loans may also be inclined to use committee schemes as a source of funds. Our data shows that 54 percent of the sample population has used committee schemes at various times as a source of funds for household investments.

\subsection{Econometric Model}

We use a straightforward test to measure the effect of ownership rights on credit access, while controlling for other variables that might also influence the latter. Since our dependent variables are binary responses, we use a maximum likelihood estimation of a binary response index model, which takes the form

$$
P(y=1 \mid x)=G(x \beta) \equiv p(x)
$$

Here, $p(x)$ is a function of $x$ alone through the index $x \beta=\beta_{1}+\beta_{2} x_{2} \ldots+\beta_{K}$ $x_{K}$ while $x$ is a vector of explanatory variables. The probit model is a special case of index models with

$$
G(z) \equiv \phi(z) \equiv \int_{-\infty}^{z} \phi(v) d v
$$

where $\phi(z)$ is the standard normal density,

$$
\phi(v)=(2 \pi)^{-\frac{1}{2}} \exp \left(-\frac{z^{2}}{2}\right)
$$

and errors are assumed to follow a standard normal distribution.

We estimate the following simple regression model:

$$
Y_{i}=\alpha+\text { jownership }_{i}+\beta X_{i}+\varepsilon_{i}
$$


$Y_{i}$ (the outcome of interest) indicates whether household $i$ recently obtained a loan from either mode of credit access, ownership $i$ indicates whether or not household $i$ owns land, and $X_{i}$ is a matrix of other covariates. These covariates include demographic variables that are basic pieces of household information and possibly related to the demand for credit, such as the household head's age, the household's monthly earnings, the percentage of income saved per month, and the household head's level of education.

Other control variables include the household's average distance from the nearest formal lender, whether or not the household uses credit cards as a mode of credit access, whether or not it uses a committee scheme, and its current state of indebtedness. The results of these regressions are discussed in the next section. The significance of the variables is judged on the basis of their $\mathrm{p}$-value.

\section{Results and Discussion}

Table 2 reports probit estimates for bank loan, formal loan, and informal loan regressions run on ownership and other household characteristics.

\subsection{Bank Loans}

Column 1 of Table 2 presents the regression results for bank loans without other sources of credit (i.e., credit cards and informal loans). The signs carried by some of the explanatory variables, such as age, education, income saved, and committee, match our hypothesized signs, but the magnitude and significance of the coefficients varies. Here, we can see that bank loans are negatively related to savings. The relationship is significant, indicating a 12.5 percent fall in the probability of taking a bank loan for households who save more than 5 percent of their income per month as compared to households who save less than 5 percent.

The other savings method used by households is the committee scheme, which may be considered a substitute both for credit cards and bank loans (sources of formal credit). As hypothesized, the sign between the committee variable and access to bank loans is negative, showing that households engaged in committee schemes are less likely to apply for bank loans. The relationship is, however, insignificant.

In theory, the relationship between bank loans and land ownership should be positive since titled owned land is expected to 
increase access to formal credit, but the regression results in Column 1 does not indicate this. The probit estimate shows that the likelihood of a household gaining access to bank loans does not change with land ownership-the two are thus observed to be unrelated.

Even when we add other sources of credit to the regression (Table 2, Column 2), bank loans and land ownership remain unrelated. One explanation for this could be the use of a small sample. Additionally, we have not included factors such as the extent to which a household might observe religious decrees, which could affect its willingness to obtain funds through bank loans as buying a loan at an interest rate is considered unlawful in Islam. ${ }^{4}$

\footnotetext{
${ }^{4}$ During the survey, many households explicitly said that they did not believe in taking loans from banks because the latter charged interest rates, which Islam does not allow.
} 
Table 2: Probit Regression Results

\begin{tabular}{|c|c|c|c|c|c|c|c|}
\hline \multirow[b]{2}{*}{ Variable } & \multicolumn{2}{|c|}{$\begin{array}{c}\text { Bank loans } \\
(1=\text { yes })\end{array}$} & \multicolumn{3}{|c|}{$\begin{array}{l}\text { Formal loans } \\
\quad(1=\text { yes })\end{array}$} & \multicolumn{2}{|c|}{$\begin{array}{c}\text { Informal loans } \\
(1=\text { yes })\end{array}$} \\
\hline & 1 & 2 & 3 & 4 & 5 & 6 & 7 \\
\hline Age 19 to 29 & $\begin{array}{c}-0.059 \\
(-0.390)\end{array}$ & $\begin{array}{c}-0.068 \\
(-0.470)\end{array}$ & $\begin{array}{l}-0.194 \\
(-0.740)\end{array}$ & $\begin{array}{c}-0.232 \\
(-0.890)\end{array}$ & $\begin{array}{l}-0.045 \\
(-0.220)\end{array}$ & $\begin{array}{l}-0.088 \\
(-0.440)\end{array}$ & $\begin{array}{c}-0.098 \\
(-0.500)\end{array}$ \\
\hline Age 30 to 55 & $\begin{array}{c}0.010 \\
(0.130)\end{array}$ & $\begin{array}{l}-0.018 \\
(-0.210)\end{array}$ & $\begin{array}{l}-0.346^{* *} \\
(-2.210)\end{array}$ & $\begin{array}{l}-0.333^{* *} \\
(-2.150)\end{array}$ & $\begin{array}{c}-0.019 \\
(-0.170)\end{array}$ & $\begin{array}{c}-0.072 \\
(-0.590)\end{array}$ & $\begin{array}{l}-0.081 \\
(-0.680)\end{array}$ \\
\hline Income saved & $\begin{array}{l}-0.125^{*} \\
(-1.690)\end{array}$ & $\begin{array}{l}-0.131^{*} \\
(-1.770)\end{array}$ & $\begin{array}{c}-0.377^{* * * *} \\
(-2.600)\end{array}$ & $\begin{array}{l}-0.350^{* *} \\
(-2.350)\end{array}$ & $\begin{array}{c}0.090 \\
(0.990)\end{array}$ & $\begin{array}{c}0.092 \\
(1.000)\end{array}$ & $\begin{array}{c}0.088 \\
(0.950)\end{array}$ \\
\hline Intermediate & $\begin{array}{c}0.001 \\
(0.010)\end{array}$ & $\begin{array}{c}-0.011 \\
(-0.060)\end{array}$ & $\begin{array}{c}-0.266 \\
(-0.730)\end{array}$ & $\begin{array}{c}-0.207 \\
(-0.540)\end{array}$ & $\begin{array}{c}0.155 \\
(0.820)\end{array}$ & $\begin{array}{c}0.180 \\
(0.940)\end{array}$ & $\begin{array}{c}0.178 \\
(0.940)\end{array}$ \\
\hline University & $\begin{array}{c}0.176 \\
(1.620)\end{array}$ & $\begin{array}{l}0.187^{*} \\
(1.710)\end{array}$ & $\begin{array}{c}0.118 \\
(0.670)\end{array}$ & $\begin{array}{c}0.142 \\
(0.800)\end{array}$ & $\begin{array}{c}0.127 \\
(0.910)\end{array}$ & $\begin{array}{c}0.117 \\
(0.830)\end{array}$ & $\begin{array}{c}0.142 \\
(0.970)\end{array}$ \\
\hline $\begin{array}{l}\text { Earn } 20,000 \text { to } \\
60,000\end{array}$ & $\begin{array}{l}-0.171^{*} \\
(-1.650)\end{array}$ & $\begin{array}{c}-0.151 \\
(-1.420)\end{array}$ & $\begin{array}{c}0.162 \\
(0.950)\end{array}$ & $\begin{array}{c}0.139 \\
(0.800)\end{array}$ & $\begin{array}{l}-0.262^{* *} \\
(-2.190)\end{array}$ & $\begin{array}{l}-0.218^{*} \\
(-1.780)\end{array}$ & $\begin{array}{l}-0.228^{*} \\
(-1.850)\end{array}$ \\
\hline $\begin{array}{l}\text { Earn above } \\
60,000\end{array}$ & $\begin{array}{c}0.172 \\
(1.260)\end{array}$ & $\begin{array}{l}0.315^{*} \\
(1.900)\end{array}$ & $\begin{array}{l}0.871^{* * *} \\
(4.970)\end{array}$ & $\begin{array}{l}0.858^{* * *} \\
(4.730)\end{array}$ & $\begin{array}{l}-0.291^{* *} \\
(-2.070)\end{array}$ & $\begin{array}{l}-0.219 \\
(-1.320)\end{array}$ & $\begin{array}{l}-0.171 \\
(-1.040)\end{array}$ \\
\hline Work to total & $\begin{array}{c}-0.138 \\
(-0.570)\end{array}$ & $\begin{array}{c}-0.026 \\
(-0.110)\end{array}$ & $\begin{array}{l}-0.412 \\
(-1.090)\end{array}$ & $\begin{array}{c}-0.527 \\
(-1.280)\end{array}$ & $\begin{array}{c}-1.067^{* * *} \\
(-2.630)\end{array}$ & $\begin{array}{c}-1.067^{* * *} \\
(-2.630)\end{array}$ & $\begin{array}{l}-1.066^{* * *} \\
(-2.640)\end{array}$ \\
\hline Credit card & - & $\begin{array}{l}-0.132^{*} \\
(-1.650)\end{array}$ & - & - & - & $\begin{array}{l}-0.194 \\
(-1.550)\end{array}$ & $\begin{array}{l}-0.219^{*} \\
(-1.790)\end{array}$ \\
\hline $\begin{array}{l}\text { Current } \\
\text { informal loan }\end{array}$ & - & $\begin{array}{c}0.105 \\
(1.360)\end{array}$ & - & $\begin{array}{l}-0.117 \\
(-0.910)\end{array}$ & & - & \\
\hline $\begin{array}{l}\text { Current formal } \\
\text { loan }\end{array}$ & & & - & & - & $\begin{array}{c}0.127 \\
(1.050)\end{array}$ & \\
\hline $\begin{array}{l}\text { Bank } \\
\text { indebtedness }\end{array}$ & & & - & & - & - & $\begin{array}{c}-0.023 \\
(-0.210)\end{array}$ \\
\hline Ownership & $\begin{array}{l}-0.052 \\
(-0.710)\end{array}$ & $\begin{array}{l}-0.023 \\
(-0.320)\end{array}$ & $\begin{array}{l}0.301^{* *} \\
(2.500)\end{array}$ & $\begin{array}{l}0.307^{* *} \\
(2.530)\end{array}$ & $\begin{array}{c}0.076 \\
(0.800)\end{array}$ & $\begin{array}{c}0.118 \\
(1.220)\end{array}$ & $\begin{array}{c}0.126 \\
(1.280)\end{array}$ \\
\hline $\begin{array}{l}\text { Average } \\
\text { distance from } \\
\text { bank }\end{array}$ & $\begin{array}{c}0.011 \\
(0.490)\end{array}$ & $\begin{array}{c}0.013 \\
(0.590)\end{array}$ & $\begin{array}{l}0.082^{* *} \\
(2.140)\end{array}$ & $\begin{array}{l}0.078^{* *} \\
(2.010)\end{array}$ & & - & \\
\hline Committee & $\begin{array}{l}-0.108 \\
(-1.600)\end{array}$ & $\begin{array}{l}-0.131^{*} \\
(-1.890)\end{array}$ & $\begin{array}{l}-0.214^{*} \\
(-1.720)\end{array}$ & $\begin{array}{l}-0.193 \\
(-1.500)\end{array}$ & $\begin{array}{c}0.076 \\
(0.860)\end{array}$ & $\begin{array}{c}0.085 \\
(0.940)\end{array}$ & $\begin{array}{c}0.071 \\
(0.800)\end{array}$ \\
\hline Pseudo-R ${ }^{2}$ & 0.222 & 0.259 & 0.520 & 0.524 & 0.118 & 0.140 & 0.135 \\
\hline $\begin{array}{l}\text { No. of } \\
\text { observations }\end{array}$ & 149 & 149 & 149 & 149 & 149 & 149 & 149 \\
\hline
\end{tabular}

Notes: z-stats are given in parentheses; ${ }^{*}, *$, and ${ }^{* *}$ indicate significance at 10,5 , and 1 percent, respectively.

Source: Author's calculations. 
The results for the other variables used in the last regression also remain the same. Savings remain negatively and significantly related to bank loans with almost the same magnitude. The committee variable also continues to show a negative-but, in this case, significant-relationship with bank loans.

We can also see that the most educated and highest earners are most likely to borrow from banks, i.e., the greater the likelihood of a household head holding a Bachelors or Master's degree, the higher his or her chances of access to bank loans compared to less educated household heads with only secondary education or less. The probit estimate shows that a household head with up to tertiary education has an 18.7 percent higher chance of obtaining a bank loan than a household head with only secondary education or less. For households earning above Rs60,000 per month, the probability of obtaining a bank loan is 31.5 percent higher than those earning below Rs20,000.

Bank loans are also negatively related to other sources of formal credit, i.e., credit cards-showing that the two are substitutes for one another-while their relationship with informal loans is positive, but insignificant. Banks are most likely to look at a household's credit card indebtedness when giving a loan, thus limiting total formal credit. Since banks cannot monitor informal loans, the relationship between informal loans and bank loan is ambiguous.

The next two regressions, therefore, combine access to credit cards and bank loans as a single source of formal loans and determine its relationship with land ownership.

\subsection{Formal Loans (Bank Loans and Credit Card Loans)}

In Table 2, Columns 3 and 4 show the regressions run on formal loans with and without access to informal loans. In both cases, the relationship between formal loans and land ownership is positive and significant at 5 percent. Column 4 reports that households who own their place of residence are 30.7 percent more likely to obtain bank loans and credit cards than households who do not.

Household heads who earn Rs60,000 a month or more have greater access to formal loans, probably because they are more likely to use credit cards than those whose incomes are less than Rs20,000. This may hold true for two reasons: (i) lower-income households have less access to formal 
financial markets and are thus limited to informal ones, and (ii) only people with higher incomes are likely to hold bank accounts and only household heads who have bank accounts are granted credit cards.

We also see that household heads aged between 30 and 55 have a lower probability of obtaining formal loans than older household heads (aged 56 or over), given a set of certain household attributes. This could be because older household heads may have greater experience, own established businesses, or have more property to offer as collateral or guarantees in order to borrow funds.

As expected, savings-both regular and committee-based-show a significant negative relationship with formal loans. Surprisingly, the relationship between formal loans and the average distance between a household and the nearest bank is positive. However, it might not be all that important a result given that borrowers likely have vehicles, making travel easier.

The relationship between current informal loans and formal loans is seen to be negative, which shows that households using informal loans are less likely to resort to formal loans as a source of funds. The current dataset, however, does not show that the relationship is significant.

Finally, looking at the bank loans and formal loans regression together, it appears that households are not being able to use their ownership rights to securitize bank loans. Only when bank loans are combined with credit cards do we see a positive significant relationship between owned land and formal credit.

\subsection{Informal Loans}

In Table 2, Columns 5, 6, and 7 present the regression results for informal loans. In theory, formally titled owned land does not have any significant impact on access to informal loans. Our results show the same: in all three regressions, informal loans do not show a significant relationship with land ownership, as hypothesized. The regression results for most variables remain the same in the three columns.

Column 5 presents the regression results for informal loans without other sources of credit. As low-income households do not have complete access to the formal financial system, they are left with informal loans as their only source of obtaining funds. This is borne out by the regressions: households earning more than Rs60,000 a month have 29.1 percent less 
chance of obtaining informal loans as compared to low-income households earning Rs20,000 or less. Similarly, the probability of obtaining informal loans falls by 26.2 percent if the household head earns between Rs20,000 and Rs60,000 as opposed to those who earn Rs20,000 or less.

As hypothesized, the variable measuring the ratio of total number of working members to total number of household members is negative and significant. In brief, the lowest-income households and those with a high dependency ratio (low work-to-total ratio) have the highest propensity to take informal loans.

Informal loans appear to be unrelated to savings, while education and age also show a statistically insignificant relationship with informal loans, although the effect of these is partially accounted for by household income. The use of committee schemes has a positive but insignificant relationship with access to informal loans, which could be because households choosing to take informal loans and use committees have similar characteristics - low incomes and high dependency ratios. Thus, it might not be wrong to say that most households who take informal loans also use committees as a source of funds.

In Columns 6 and 7, we add sources of formal credit to our analysis. The use of credit cards shows a negative and significant relationship with informal loans, suggesting that household heads already using credit cards have a lower probability of taking informal loans than those who do not use credit cards. The two appear to act as substitutes for one another as sources of short-term credit. An interesting question here is whether households take informal loans to repay formal loans. To answer this, we add the variable of bank indebtedness to our regression in Column 7, which shows that households already in debt to a bank do not seem to use informal loans to repay formal loans.

\section{Conclusion}

The main assertion of this article has been that ownership rights allow urban households in Lahore greater access to credit markets by using owned land as collateral. Despite the limitations of using a small sample size, our results yield some interesting findings.

The probit estimate of the bank loan variable regressed on the ownership variable indicates that the likelihood of a household gaining access to bank loans does not change with land ownership as shown by 
Field and Torero (2006) for private loans. The regression does not include factors such as the degree to which a household observes religious decrees concerning interest, although this could affect its willingness to obtain funds through bank loans, as buying a loan on an interest rate is considered unlawful in Islam.

In addition, bank loans are negatively related to the use of credit cards, showing that banks might monitor a household's credit card indebtedness when providing a loan, thus limiting the former's total formal credit, or that individuals choose to use credit cards instead of bank loans. For individuals, the costs of applying for a formal loan may deter them from submitting an application. For banks, the cost of formal procedures of collateral processing, foreclosure, and resale is large relative to the average size of a loan, which may also restrict the use of owned land as collateral by such households in gaining access to bank loans.

When credit cards and bank loans are combined as one variable, i.e., formal loans, we see a significant positive relationship between land ownership and access to formal loans. Households who own their place of residence have a 30.7 percent higher chance of obtaining formal loans compared to households who do not.

Our results also show an insignificant relationship between land ownership and informal loans. We observe that households with the lowest income and high dependency ratio (low work-to-total ratio) have the highest propensity to take informal loans, as shown by our probit estimates. Moreover, credit cards and informal loans appear to be substitutes for one another as sources of short-term credit.

The reason for the limited impact of ownership on bank loans may be the limited supply of formal credit. The study suggests that, in order to understand the effect of land ownership on access to credit, one also needs to incorporate banking practices into the analysis. 


\section{References}

Alston, L. J., Libecap, G. D., \& Schneider, R. (1996). The determinants and impact of property rights: Land titles on the Brazilian frontier. Journal of Law, Economics, and Organization, 12(1), 25-61.

Bardhan, P. (1989). Alternative approaches to the theory of institutions in economic development. In P. Bardhan (Ed.), The economic theory of agrarian institutions. Oxford, UK: Clarendon Press.

Besley, T. (1995). Property rights and investment incentives: Theory and evidence from Ghana. Journal of Political Economy, 103(5), 903-937.

Brasselle, A. S., Gaspart, F., \& Platteau, J.-P. (2002). Land tenure security and investment incentives: Puzzling evidence from Burkina Faso. Journal of Development Economics, 67, 373-418.

Carter, M. R, \& Olinto, P. (2003). Getting institutions "right" for whom? Credit constraints and the impact of property rights on the quantity and composition of investment. American Journal of Agricultural Economics, 85(1), 173-86.

De Laiglesia, J. R. (2004). Investment and credit effects of land titling and registration: Evidence from Nicaragua. Mimeo, London School of Economics, UK.

De Soto, H. (2000). The mystery of capital: Why capitalism triumphs in the West and fails everywhere else. London, UK: Black Swan.

Deininger, K. (2003). Land policies for growth and poverty reduction. Washington, DC: World Bank.

Deininger, K., \& Binswanger, H. (1999). The evolution of the World Bank's land policy: Principles, experience, and future challenges. World Bank Research Observer, 14(2), 247-276.

Deininger, K., \& Feder, G. (2001). Land institutions and land markets. In Handbook of Agricultural Economics (Vol. 1, Part A, pp. 288-331). doi:10.1016/S1574-0072(01)10009-5

Dower, P., \& Potamites, E. (2010). Signaling credit worthiness: Land titles, banking practices and access to formal credit in Indonesia (Working 
Paper No. W0155). New York, NY: Center for Economic and Financial Research.

Feder, G., Onchan, T., Chalamwong, Y., \& Hongladarom, C. (1988). Land policies and farm productivity in Thailand. Baltimore, MD: Johns Hopkins University Press.

Feder, G., \& Nishio, A. (1996, November). The benefits of land registration and titling: Economic and social perspectives. Paper presented at the International Conference on Land Tenure and Administration, Orlando, FL.

Field, E. (2005). Property rights and investment in urban slums. Journal of the European Economic Association, Papers and Proceedings, 3(2-3), 279-290.

Field, E., \& Torero, M. (2006). Do property titles increase credit access among the urban poor? Evidence from a nationwide titling program. Mimeo, Harvard University, Cambridge, MA.

Galiani, S., \& Schargrodsky, E. (2010). Property rights for the poor: Effects of land titling. Journal of Public Economics, 94(9-10), 700-729.

Hayes, J., Roth, M., \& Zepeda, L. (1997). Tenure security, investment and productivity in Gambian agriculture: A generalized probit analysis. American Journal of Agricultural Economics, 79(2), 369-382.

Johnson, S., McMillan, J., \& Woodruff, C. (2002). Property rights and finance. American Economic Review, 92, 1335-1356.

Lopez, R. (1996). Land titles and farm productivity in Honduras. Mimeo, Department of Agricultural and Resource Economics, University of Maryland, College Park.

Pender, J., \& Kerr, J. M. (1999). The effects of land sales restrictions: Evidence from South India. Agricultural Economics, 21(3), 279-294.

Petracco, C. K., \& Pender, J. (2009). Evaluating the impact of land tenure and titling on access to credit in Uganda (IFRPI Discussion Paper No. 00853). Washington, DC: International Food Policy Research Institute. 
Place, F., \& Migot-Adholla, S. (1998). The economic effects of land registration for smallholder farms in Kenya: Evidence from Nyeri and Kakamega districts. Land Economics, 74(3), 360-373.

Platteau, J.-P. (2000). Institutions, social norms, and economic development. Reading, UK: Hardwood Academic.

Roth, M., Cochrane, J., \& Kisamba-Mugerwa, W. (1994). Tenure security, credit use, and farm investment in the Rujumbura pilot land registration scheme, Uganda. In J. W. Bruce \& S. Migot-Adholla (Eds.), Searching for land tenure security in Africa (pp. 169-198). Dubuque, IA: Kendall/Hunt Publishing Co.

Stiglitz, J., \& Weiss, A. (1981). Credit rationing and markets with imperfect information. American Economic Review, 71(3), 393-411.

Tassel, E. (2004). Credit access and transferable rights. Oxford Economic Papers, 56, 151-166.

Wette, C. H. (1983). Collateral in credit rationing markets with imperfect information: Note. American Economic Review, 73(3), 442-445.

Woodruff, C. (2001). Review of De Soto's "The mystery of capital." Journal of Economic Literature, 39(4), 1215-1223.

Wooldridge, W. M. (2001). Econometric analysis of cross-section and panel data. Cambridge, MA: MIT Press. 


\section{Appendix}

\section{Questionnaire}

\section{Economic Effects of Ownership Rights in Urban Lahore}

General Information

1. Area?

2. Language of interview?

- Urdu

- English

- Punjabi

- Other (specify)

3. Your age group?

- $18-29$

- $\quad 30-42$

- $\quad 43-55$

- 56 or above

4. Gender?

- Male

- Female

5. What is the highest level of education completed by your male parent?

- No education

- Primary/secondary/matriculation

- Intermediate/higher secondary

- Bachelor's

- Master's 
6. Occupation?

Monthly earnings of your household?

- $\quad$ Below Rs7,500

- Between Rs7,500 and Rs20,000

- Between Rs20,000 and Rs60,000

- Between Rs60,000 and Rs90,000

- Above Rs90,000

7. Do you rent out part of your residence?

- Yes

- No

8. If yes, then what is your monthly rental income?

- Below Rs15,000

- Rs15,000 to Rs30,000

- Rs30,000 to Rs50,000

- Rs50,000 or more

9. Do you run any home business?

- Yes

- No

10. If yes, then what is the average monthly income that you earn from it?

11. Do you earn any additional income from foreign remittances?

- Yes

- No 
12. If yes, then what is your additional monthly income from foreign remittances?

- Below Rs15,000

- Rs15,000 to Rs30,000

- Rs30,000 to Rs50,000

- Rs50,000 or more

13. Are there any additional income sources apart from those mentioned above?

- Yes

- No

14. If yes, then what is your estimated income from this/these source(s)?

15. What percentage of your income is saved per month?

- Below 5 percent

- 5-10 percent

- 10-20 percent

- 20-30 percent

- 30 percent or above

Property Rights

1. Do you possess a registered title for this land?

- Yes

- No If yes, for how many years?

2. Which of the following describes your resident status? Choose one.

- Owner

- Rented

- Government-subsidized

- Squatter

- Other 
3. Number of household members?

\begin{tabular}{lll}
\hline Male & Female & Total \\
\hline
\end{tabular}

4. Number of working members?

5. Gender of household head?

- Male

- Female

Credit Access

1. Have you taken loans from a bank lately?

- Yes

- No If yes, then how many times?

2. Amount of loan taken

3. Interest rate charged

4. If no, then do you want to try ranges for loan amounts and interest rates? Loan amounts Interest rates

- Less than Rs50,000 Less than 10 percent

- Rs50,000-100,000 11-15 percent

- Rs100,000-250,000 15-25 percent

- More than Rs250,000

5. Reason for taking the loan?

- Wedding

- Education

- Health

- Business loan

- To buy a car

- Other 
6. How many times in TOTAL have you applied for a loan?

7. Were you asked for collateral?

- Yes

- No

8. If yes, then what were the types of collateral that you were asked for?

- Land

- Factory

- Home

- Vehicles, e.g., car

- Jewelry/gold

- Other

9. Do you have a bank account?

- Yes

- No

10. If yes, then what type of account is it?

- Checking

- Savings

- Other

11. How far is your bank's branch from your house?

12. Have you ever taken loans through credit cards?

- Yes

- No If yes then what was the credit limit?

13. Apart from taking a loan from a bank, have you taken a loan from:

- A friend

- A relative

- Other

- Local unregistered moneylender

Amount given 
14. Do you currently owe a bank any money?

- Yes

- No

15. Do you currently owe money to someone else?

- Yes

- No If yes, then how much?

16. Have you used a committee to raise money for a large purchase?

- Yes

- No

17. If so, what is the order of payments?

- Lottery

- Random

- Other

18. Have you applied for a mortgage?

- Yes

- No

19. If yes, then what interest rate was offered to you and when?

- Less than 10 percent

- $10-13$ percent

- 13-16 percent

- 16 percent or above

Year 